\title{
Altered expression pattern of miR-29a, miR-29b and the target genes in myeloid leukemia
}

\author{
Ling X $\mathrm{u}^{1}$, Yan $\mathrm{Xu}^{1,2}$, Zhenyi Jing ${ }^{1}$, Xu Wang ${ }^{1,2}$, Xianfeng Zha ${ }^{3}$, Chengwu Zeng ${ }^{2}$, Shaohua Chen ${ }^{1}$, Lijian Yang ${ }^{1}$,
} Gengxin Luo ${ }^{1}, \mathrm{BO} \mathrm{Li}^{\mathrm{i}^{*}}$ and Yangqiu Li $\mathrm{Li}^{1,{ }^{*}}$

\begin{abstract}
Objectives: The miR-29 family have been demonstrated acting as vital tumor suppressor in multiple cancers as well as regulators in the adaptive immune system. Little is known about their role in leukemogenesis. The purpose of this study is to analyze the expression pattern of miR-29a/29b and its target genes Mcl-1 (myeloid cell leukemia sequence 1) and B-cell lymphoma 2 (Bcl-2) in myeloid leukemia.
\end{abstract}

Methods: Quantitative real-time PCR was used for detecting genes expression level in peripheral blood mononuclear cells (PBMCs) from 10 cases with newly diagnosed, untreated acute myeloid leukemia (AML) and 14 cases with newly diagnosed, untreated chronic myeloid leukemia (CML) in chronic phase, and 14 healthy individual $(\mathrm{HI})$ served as controls. Correlation between the relative expression levels of different genes have been analyzed.

Results: Significant lower expression of miR-29a/29b and higher expression level of two potential target genes $\mathrm{BCl}-2$ and $\mathrm{MCl}-1$ were found in PBMCs from AML and CML patients compared with HI group. In addtion, miR-29a expression in AML was significantly lower than that in CML. Moreover, negative correlation between miR-29a/29b and its target genes have been found. While, positive correlation between relative expression level of miR-29a and miR-29b or Bcl-2 and $\mathrm{Mcl}-1$ were presented in the total 38 research objects.

Conclusion: Down-regulated miR-29a and miR-29b, and accompanying up-regulated $\mathrm{BCl}-2$ and $\mathrm{Mcl}-1$ are the common feature in myeloid leukemias. These data further support the role for miR-29a/29b dysregulation in myeloid leukemogenesis and the therapeutic promise of regulating miR-29a/29b expression for myeloid leukemia in the future.

\section{Background}

Myeloid leukemia include acute myeloid leukemia (AML) and chronic myeloid leukemia (CML). AML is a heterogeneous disease, characterized by the uncontrolled proliferation of granulocytic, monocytic, megakaryocytic, or rarely, erythroid blast cells [1]. Many different cytogenetic and molecular abnormalities have been demonstrated to be involved in tumorigenesis and tumor progression of this malignancy. The distinct feature of leukemogenesis in AML is differentiation arrest and proliferative advantage of myeloid progenitors [2]. While, CML is a disease of hematopoietic stem cells, arising from a translocation $\mathrm{t}(9 ; 22)(\mathrm{q} 34 ; \mathrm{q} 11)$, known as the Philadelphia chromosome.

\footnotetext{
* Correspondence: jnlibo517@163.com; yangqiuli@hotmail.com

${ }^{1}$ Institute of Hematology, Medical College, Jinan University, Guangzhou 510632, China

${ }^{2}$ Key Laboratory for Regenerative Medicine of Ministry of Education, Jinan University, Guangzhou 510632, China

Full list of author information is available at the end of the article
}

This translocation leads to a juxtaposition of the $\mathrm{ABL}$ gene from chromosome 9 and the BCR gene from chromosome 22 , resulting in a BCR-ABL fusion gene that codes for BCR-ABL transcripts and fusion proteins with unusual tyrosine-kinase activity. The molecular pathogenesis of CML is well understood, but the molecular mechanism that leads to the gene translocation is unknown [3].

In recent years, microRNAs (miRNAs) have received wide attention as important regulators of gene expression in leukemogenesis and as an anticancer therapy target. miRNAs are 18 to 24 nucleotides (nt) in length that regulate gene expression, for the most part, by targeting mRNAs according to the degree of complementarity with their 3-untranslated region (3'-UTR). miRNAs are involved in the regulation of critical biologic processes, including normal cell homeostasis, cell metastasis and disease pathogensis and progression [4-7]. Recently, expression of miRNAs has been demonstrated to be altered in AML and 
CML, which may be related to leukemogenesis [8,9]. Distinctive patterns of increased expression and/or silencing of multiple miRNAs are associated with specific cytogenetic and molecular subsets of myeloid leukemia [10]. Changes in the expression of several miRNAs altered in AML have functional relevance in leukemogenesis, with some miRNAs acting as oncogenes and the others as tumor suppressors [11-14]. miR-29 is a very important miRNA family whose members are increasingly recognized as tumor suppressors in a variety of malignancies such as in chronic lymphocytic leukemia (CLL), mantle cell lymphoma (MCL), lung cancer, hepatocelluar carcinoma (HCC) and so on. In contrast to the majority of studies highlighting tumorsuppressive properties [15-18], opposing expression patterns and roles seem to exist in breast cancer and primary melanoma [19,20]. Moreover, it is crucial to identify target genes of miR-29s in different cancer as well as in leukemia in order to decipher cancer-associated cellular pathways and networks that might be regulated by miR-29. Based on those reasons, the number of confirmed targets for miR-29 family members is constantly rising, including many different protein classes ranging from transcription factors, viral proteins to growth factors, structural cell components, antiapoptosis genes and others [21].

To investigate the encoding of miRNA genes and the targets of miRNA, a lots of computational methods have been devised [22]. Mcl-1 (myeloid cell leukemia sequence 1) and Bcl-2 (B-cell CLL/lymphoma 2) have been predicted as potential target genes of miR-29 family and both of them belong to Bcl-2 family which play central roles in cell death regulation and alterations in their expression and function contribute to the pathogenesis and progression of human cancers [23]. In addition, Mcl-1 have been experimentally validated to be direct miR-29 target in multiple cell types $[4,18,24]$, for example, miR-29a and -29b target Mcl-1 and induces apoptosis in AML have been validated in a research target primary AML samples [24]. Bcl-2, another anti-apoptotic gene of Bcl-2 family, have been up-regulated by the decreased expression level of miR-29 and characterized as target of the miR-29 family in the signaling pathway of hepatocarcinogenesis [18]. It would be interesting to investigate whether Bcl-2 also is one of the target of miR-29 family and contribute to the molecular etiology of AML and CML alone with Mcl-1. Characterization the regulation mechanism between miR29 and these two anti-apoptosis genes in AML and CML would be important for us to further understand the pathogenetic mechanism in AML and CML.

\section{Materials and methods Samples}

The study included 24 de novo and untreated myeloid leukemia patients (10 cases with AML and 14 cases with CML, 11 males and 13 females with a median age of
31 years and a range of 15-71 years). A total of 14 healthy individuals (seven males and seven females with a median age of 30 years and a range of 23-65years) served as the control group. Informed consent was obtained from all patients. The peripheral bloods samples were collected and peripheral blood mononuclear cells (PBMCs) were isolated using Ficoll-Hypaque gradient centrifugation method [25]. RNA was extracted using the Trizol kit (Invitrogen, Carlsbad, CA, USA) and then reverse-transcribed into cDNA for miRNA29 assay using the miScriptIIRT Kit (Qiagen, Duesseldorf, Germany) and reverse-transcribed into first-strand cDNA for target genes assay using random hexamer primers and the high Capacity cDNA Reverse Transcription kit (ABI, Carlsbad, CA, USA) according to the manufacturer's instructions.

Our research obtained approval by Ethics Committee of Medical School of JINAN University of Guangdong Province of China and all the procedures were conducted according to the guidelines of the Medical Ethics committees of the health bureau of Guangdong Province of China.

\section{Quantitative real-time quantitative reverse transcription- polymerase chain reaction(qRT-PCR)}

SYBR green qRT-PCR assay was used for miR-29a and miR-29b quantification. qRT -PCR assays were carried out in a CFX96 Fast real-time PCR system (Bio-Rad, California, USA) using miScript SYBR Green PCR kit (Qiagen, Duesseldorf, Germany.). Each reaction was performed in a final volume of $25 \mu$ l containing $2 \mu \mathrm{l}$ of the cDNA, $2.5 \mu \mathrm{l}$ of each primer, $2.5 \mu \mathrm{l}$ of universal primer and $12.5 \mu \mathrm{l} 2 \times$ QuantiTect SYBR Green PCR Master Mix (Qiagen, Duesseldorf, Germany). The amplification profile was denaturation at $95^{\circ} \mathrm{C}$ for $15 \mathrm{~min}$, followed by 40 cycles of $94^{\circ} \mathrm{C}$ for $15 \mathrm{~s}, 55^{\circ} \mathrm{C}$ for $30 \mathrm{~s}$, and $70^{\circ} \mathrm{C}$ for $30 \mathrm{~s}$. At the end of the PCR cycles, melting curve analyses were performed as well as electrophoresis of the products on $1.5 \%$ agarose gels in order to validate the specific generation of the expected PCR product. The expression levels of miRNAs were normalized to RNU6B snRNA. Primers used for miRNAs analysis were purchased from Qiagene company and listed in Table 1 . The expression levels of $\mathrm{Bcl}-2, \mathrm{Mcl}-1$ and the $\beta 2$-microglobulin

\section{Table 1 Sequences of miRNA primers used in real-time} PCR

\begin{tabular}{lll}
\hline Primer & Product imformation & $\begin{array}{l}\text { Mature miRNA } \\
\text { Sequence }\left(5^{\prime}-\mathbf{3}^{\prime}\right)\end{array}$ \\
\hline miR-29a & $\begin{array}{l}\text { Hs_miR-29a_1 miScript } \\
\text { Primer Assay }\end{array}$ & $\begin{array}{l}\text { UAGCACCAUCUGAAAU } \\
\text { CGGUUA }\end{array}$ \\
miR-29b & Hs_miR-29b_1 miScript & UAGCACCAUUUGAAAU \\
& Primer Assay & CAGUGU \\
RNU6-2 & Hs_RNU6-2_11 miScript & ACGCAAATTCGTGAAG \\
& Primer Assay & CGTT \\
\hline
\end{tabular}


( $\beta 2-\mathrm{MG})$ reference gene were determined by SYBR Green I real-time PCR as our previous description [26]. The primers used for real-time PCR for the three gene amplifications were listed in Table 2 and were synthesized by Shanghai Biological Engineering Technology Services Co. Ltd. Random PCR products from all detected genes were also sent to Shanghai Invitrogen Biotechnology Co. for DNA sequence analysis.

\section{Statistical analysis}

Univariate analyses were done using the student's t-test to compare means of miR-29a/b expression levels between $\mathrm{HI}$ group and AML or CML group,and between two kinds of myeloid leukemia group. Kruskal-Wallis Test was used to analyses the expression levels of Bcl-2 and Mcl-1 among HI, AML and CML group. Pearson correlation and linear regression analysis was used to estimate the correlation between expression level of miR-29a/ $\mathrm{b}$ and its target genes from all the groups. All statistical tests were two-sided, and $P$ values less than 0.05 were considered as statistically significant. All analyses were performed using SPSS software (version 13.0, SPSS).

\section{Results}

Decreased expression of miR-29a and miR-29b in myeloid leukemia

Positive PCR products for each detedcted gene from qRTPCR assay were confirmed by agarose gel electrophoresis, the PCR product direct sequencing also confirmed the specific amplification (data not shown). The results demonstrated the downregulation of miR-29a and miR-29b in myeloid leukemia. miR-29a expression was significantly reduced in PBMCs of AML $(2.62 \pm 2.63)(\mathrm{p}<0.0001)$ and CML $(9.88 \pm 5.73)(\mathrm{p}<0.0001)$ compared with healthy individuals (HI) $(73.97 \pm 15.82)$ (Figure 1A). Similar results were found in miR-29b, its expression levels were significantly lower in AML $(4.68 \pm 2.94)(\mathrm{p}<0.0001)$ and CML $(4.07 \pm 3.28)(\mathrm{p}<0.0001)$ than that in HI group $(31.94 \pm$ 12.25) (Figure 1B). In addtion, miR-29a expression in AML samples was significantly lower than that in CML samples ( $\mathrm{p}<0.0001)$. Although miR-29b expression in CML samples also lower than in AML samples, the difference is statistically insignificant $(\mathrm{p}=0.664)$.

Table 2 Sequences of target gene primers used in real-time PCR

\begin{tabular}{llc}
\hline Primer & Sequence & PCR products (bp) \\
\hline BCl-2-f & 5'-GATGACTTCTCTCGGCGCTACC-3' & 126 \\
BCl-2-r & 5'-GTTCACCCCGTCCCTGAAGA-3' & \\
Mcl-1-f & 5'-GGGCAGGATTGTGACTCTCATT-3' & 79 \\
Mcl-1-r & 5'-GATGCAGCTTTCTTGGTTTATGG-3' & \\
B2M-f & 5'-TACACTGAATTCACCCCCAC-3' & 144 \\
B2M-r & 5'-CATCCAATCCAAATGCGGCA-3' & \\
\hline
\end{tabular}

Increased expression of BCL-2 and MCL-1 in myeloid leukemia

According to the information by miRWalk (http://mir walk.uni-hd.de/), a comprehensive database that provides predicted as well as validated miRNA binding site information on miRNAs for human, mouse and rat [27]. There are a lot of target genes for miR-29a and miR-29b, such as DNMTs (DNA-methytransferases), T-bet (T-box transcription factor) and CDK6(Cyclin-dependent kinase 6) and so on $[16,28,29]$, among them, we focused on two target genes (Bcl-2 and $\mathrm{Mcl}-1$ ), both of them are the predicted and validated target genes of miR-29a and miR$29 \mathrm{~b}$, and may relate to meyloid leukemogenesis $[4,18,24]$. We detected the expression levels of Bcl-2 and $\mathrm{Mcl}-1$ gene in PBMCs from AML and CML, as well as HI groups, the data was presented using median. We observed an different expression pattern of the two genes among different groups:Bcl-2 (median: $0.53>0.33>0.11, \mathrm{p}=0.002$ ) (Figure 2A), Mcl-1 (median: $18.82>13.31>5.91, \mathrm{p}<0.0001$ ) (Figure 2B). The expression level of $\mathrm{Bcl}-2$ was significant increased in AML (median: 0.53) $(\mathrm{p}<0.0001)$ and $\mathrm{CML}$ (median: 0.33$)(\mathrm{p}=0.007)$ groups compared with HI group (median: 0.11). Same results was found in Mcl-1, its expression level was also significant increased in AML (median: 18.82) $(\mathrm{p}<0.0001)$ and CML (median: 13.31) $(\mathrm{p}<0.0001)$ groups in comparison with HI group (median: 5.91). In addition, we can observe a higher expression of Bcl-2 ( $\mathrm{p}=0.508)$ and $\mathrm{Mcl}-1(\mathrm{p}=0.042)$ in AML than $\mathrm{CML}$, however, the difference of $\mathrm{Bcl}-2$ have no significant.

\section{Negative correlation expression of miR-29 and the target genes}

Correlation analysis of the relative expression levels of $\mathrm{miR}-29 \mathrm{a} / \mathrm{b}$ and the target genes in the total 38 study objects from HI, AML and CML groups was performed using Spearman's rank correlation analysis,. A negative expression correlation level for miR-29a and the two target genes (Bcl-2: rs $=-0.572, \mathrm{p}<0.0001 ; \mathrm{Mcl}-1$ : $\mathrm{rs}=-0.625$, $\mathrm{p}<0.0001$ ) (Figure $3 \mathrm{~A}$ and $3 \mathrm{~B}$ ), as well as a negative expression correlation level for genes miR-29b and the two target genes (Bcl-2: $\quad$ rs $=-0.498, \mathrm{P}=0.001 ; \mathrm{Mcl}-1$ : $\mathrm{rs}=-0.529, \mathrm{p}=0.001$ ) (Figure $3 \mathrm{C}$ and $3 \mathrm{D}$ ) was found, when the correlation analysis was performed in all 38 samples, while there was no significant correlation between the expression levels of miR-29a/b and the two target genes when analysis in the each single group. Moreover, correlation analysis of the relative expression levels of miR29a and miR-29b in the 38 total research objects showed a positive correlation ( $\mathrm{rs}=0.758, \mathrm{p}<0.0001$ ) (Figure 4A), however, there was no significant correlation between the expression levels of miR-29a and miR-29b when analysis in the single group. And the expression levels between Bcl-2 and $\mathrm{Mcl}-1$ genes showed an weak positive correlation ( $\mathrm{rs}=$ 0.474, $\mathrm{p}=0.003$ ) (Figure 4B). 

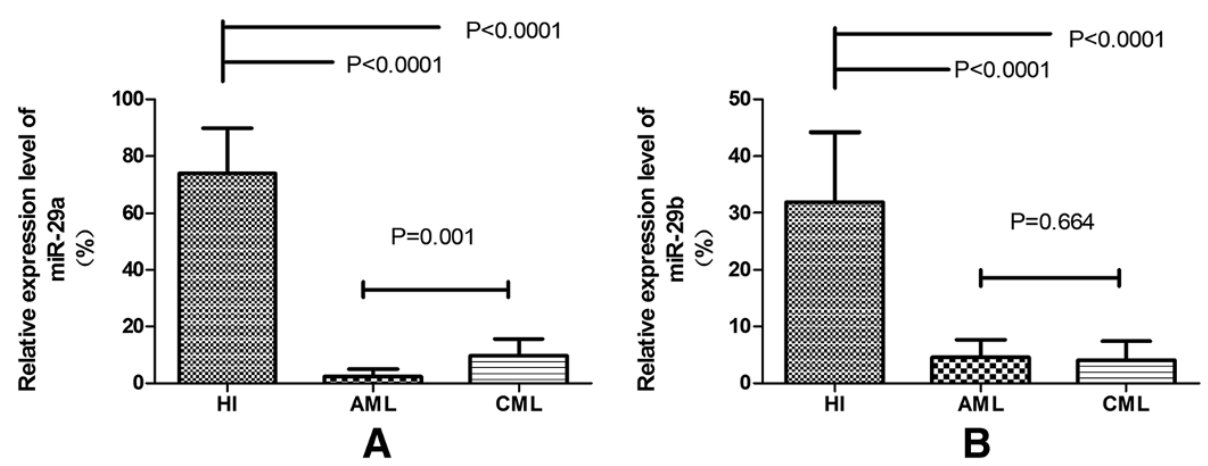

Figure 1 The relative expression level of miR-29a and miR-29b in PBMCs from AML,CML and healthy (HI) groups. (A) miR-29a expression level down-regulated in AML and CML; (B) miR-29b expression level down-regulated in AML and CML.

\section{Discussion}

Recent studies corroborate on the potential use of miR29 family as predictive biomarkers for early diagnosis of malignancies and other diseases, however, the exprssion pattern of miR-29 in myeloid leukemia haven't been assessed accurately and their regulation mechanism in the pathological process of AML remain unclear. In this study, we reported the down-regulation expression of miR-29a and miR-29b in PBMCs of AML patients which is similar to Zhang's study, they identified miR-29a and miR-142-3p down-regulated in PBMCs from AML, and suggested that may serve as potential biomarkers and therapeutic targets for AML [30]. In addition, several studies showed that the universal down-regulated miR-29 family members have been found in different AML. For example, down-regulation of miR-29a, miR-29b and miR-29c in patients with balanced 11q23 translocations versus all other AML patients have been reported [31], while miR-29a and miR-29c were upregulated in AML with a good prognosis, such as $\mathrm{NPMc}^{+} \mathrm{AML}$ (aberrant cytoplasmic NPM1 localization) compared with $\mathrm{NPMc}^{-}$ (unmutated) AML which is with a bad prognosis [32]. All of these results supported that miR-29 family serves as tumor suppressor role in pathogenesis of AML and increasing endogenous expression or ectopic implantation of miR-29a may be a potential strategy for AML treatment. In contrast, another research demonstrated that miR-29a expression in the purified leukemia stem cell (LSC) and non-LSC blast populations were significantly increased compared with common myeloid progenitors (CMP), their data suggest that miR-29a may play a oncogene in human myeloid leukemogenesis [33]. This difference may due to the different control groups used in respective research, or may indicate that miR-29a has different regulating function in different leukemia cells, similar reports such as miR17-92 cluster plays oncogene in B-cell lymphoma, lung cancers, rhabdomyosarcoma and liposarcoma while plays tumor suppressor in hepatocellular carcinomas (HCC) and cervical cancer cell line, further research should be pay attention to appropriate controls and more accurate cell differenciation stage so that we can conduct a more comprehensive analysis for the expression pattern and function of miR-29 in myeloid leukemia.

Few studies described that the expression pattern of miR-29 family members in CML patients [34-37]. Recently, San José-Enériz E et al. reported that miR-29a, miR-29c
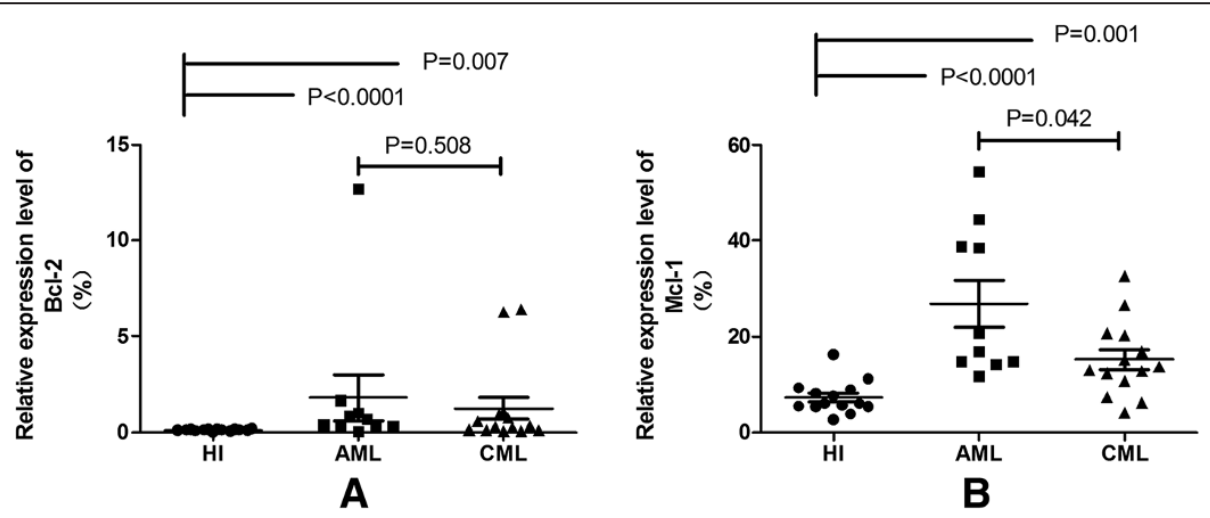

Figure 2 The relative expression level of $\mathrm{BCl}-2$ and $\mathrm{Mcl}-1$ in PBMCs from AML,CML and healthy (HI) groups. (A) BCl-2 expression level is up-regulated in AML and CML; (B) Mcl-1 expression level is up-regulated in AML and CML. 

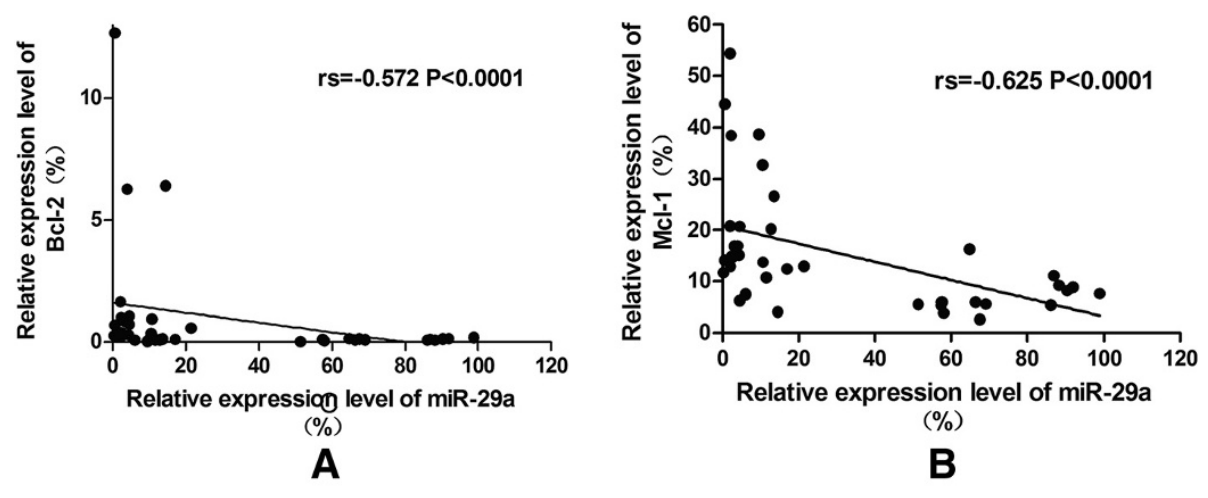

(\%)
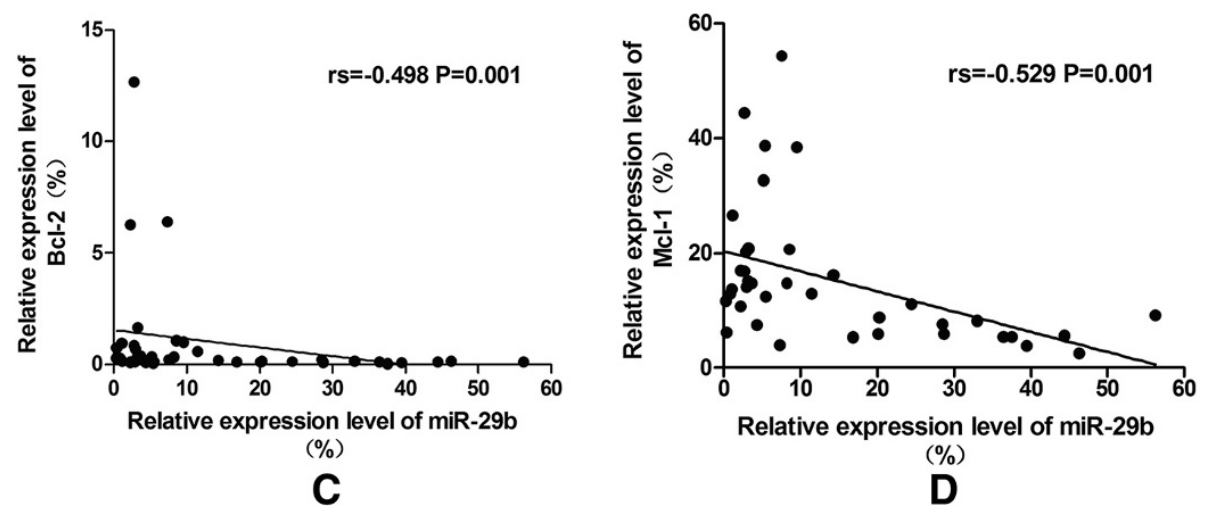

Figure 3 The negative correlation between miR-29a/29b and target genes in 38 research objects was indicated. (A) miR-29a vs. Bcl-2; (B) miR-29a vs. BCl-2; (C) miR-29b vs. Bcl-2; (D) miR-29b vs. Mcl-1.

and other 17 miRNAs were downregulated and could possiblely predict the clinical resistance to imatinib in patients with newly diagnosed CML [34]. In the present study, we also found the down-regulation of miR-29a/miR-29b in PBMCs from CML patients, which is consistent with the microarray results of miR-29b downregulated in leukemia cells form bone marrow of CML blast crisis and RT-PCR results from $5 \mathrm{CML}$ patients reported by $\mathrm{Li}$ et al. [36]. From current research data, a prominent downregulation of miR-29a/b in CML might indicate miR-29a/29b as potential tumor suppressor in CML, however, it is needed further comfirmation.

The different expression pattern of miR-29a/miR-29b in AML and CML also have been observed in our study, lower expression of miR-29a in AML compared with CML, similar tendency was found in miR-29b, this may be due to the various stage of maturation of leukemia cells, however, further investigation to characterize the expression feature in different myeloid leukimia subtype is needed with larger sample size.

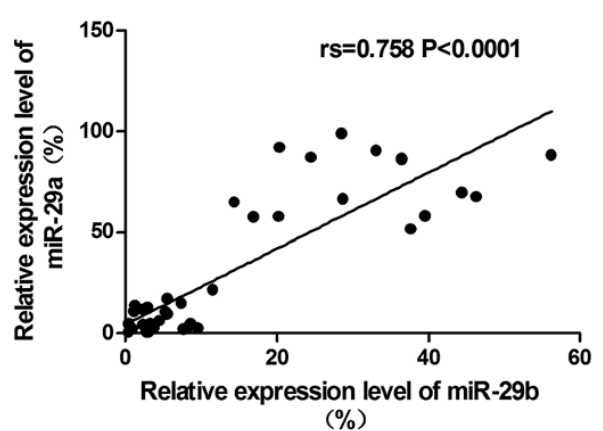

A

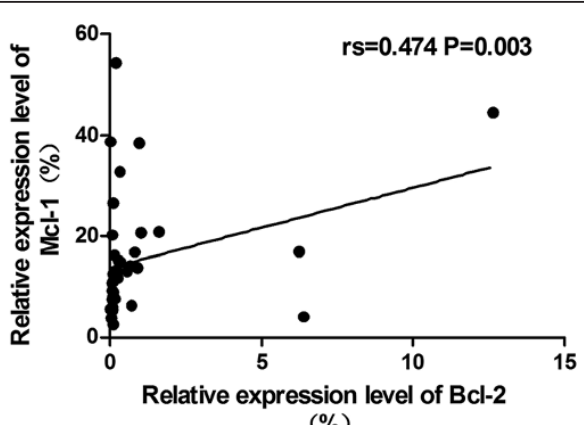

(\%)

Figure 4 The positive correlation between miR-29 members as well as between target genes. (A) A positive correlation between miR-29a and miR-29b was indicated; (B) A weak positive correlation between $\mathrm{BCl}-2$ and $\mathrm{MCl}-1$ was indicated. 
For further understand the characteristic of expression and regulation of miR-29 in myeloid leukemia, we searched from miRWalk datebase and found two antiapoptotic genes Mcl-1 and Bcl-2, which are target genes by both miR-29a and miR-29b and highly correlate to myeloid leukemia. As expected we found that Mcl-1 and Bcl-2 were up-regulated in PBMCs from AML patients and negatively correlated with miR-29a/miR-29b expression. Overexpression of Mcl-1 has been reported in cancer, including in AML at relapse [38]. Mcl-1 was negatively regulated by miR-29 $\mathrm{s}$ at mRNA level as well as protein level in several different diseases according to 3 '-UTR binding $[18,24,39]$. The current result also showed the same tendency in AML patients at mRNA level, meanwhile, we also showed the same potential regulation pathway in CML which may haven't been characterized before.

Several previous studies found that high expression of $\mathrm{Bcl}-2$ associate with a low complete remission rate after intensive chemotherapy and with a significantly shorter survival of AML patients [40,41]. The reason of Bcl-2 overexpression may due to chromosomal translocations, gene amplification, epigenetic regulation and so on in lymphoma [42-44]. Besides, loss of endogenous miRNAs repress $\mathrm{Bcl}-2$ gene expression had been documented in CLL and human gastric cancer $[45,46]$. Recently, a research demonstrated that down-regulation of miR-29 was a frequent event in HCC tissues and independent prognosis predictor for $\mathrm{HCC}$ patients, and $\mathrm{Bcl}-2$ and Mcl-1 as functional targets of miR-29 involved in the mitochondrial pathway in miR-29 promoted apoptosis [18]. In this study, we observed a negative correlation between miR-29a/miR-29b and Bcl-2 or Mcl-1 in AML and CML, suggesting that there may exist a similar regulation pathway in AML and CML which have been discovered in HCC. It had been demonstrated that miR29b could impact CML cell proliferation and induces apoptosis via regulation of $\mathrm{BCR} / \mathrm{ABL} 1$ protein and RNase-L [36,37]. Our data may provide more information about the mechanism of the effect of downregulating miR-29a/miR-29b in CML. Suggesting that Mcl-1 and $\mathrm{Bcl}-2$ also regulated by miR-29a and miR-29b at post-transcriptional level and both of them contribute to the blocked apoptosis of leukemia cells in CML. Further research will focus on whether Mcl-1 and Bcl-2 could be directly target by miR-29 and miR-29b and how will they work in leukemia cells.

In conclusion, we characterized the expression feature of miR-29a/miR-29b and their target genes Mcl-1 and $\mathrm{Bcl}-2$ in Chinese AML and CML patients. We also revealed that miR-29a/miR-29b negatively correlated with Mcl-1 and Bcl-2 in AML and CML. The data may support the finding of miR-29a and miR-29b as tumor suppressors. Further investigation is needed to confirm whether Mcl-1 and Bcl-2 could be directly regulate by miR-29, and whether miR-29 could be a effective biomarker and therapeutic target.

\section{Conclusions and future directions}

Down-regulated miR-29a and miR-29b associated with up-regulated Bcl-2 and Mcl-1 in myeloid leukemias indicate that $\mathrm{miR}-29 \mathrm{a} / \mathrm{miR}-29 \mathrm{~b}$ may contribute to the antiapoptosis of myeloid leukemia cells according to binding with 3'-UTR of Bcl-2 and Mcl-1 genes, further investigations will focus on the function of miR-29a and miR-29b in myeloid leukemia and their interaction with Bcl-2 and Mcl-1. Our current data support the role for miR-29a/ $29 \mathrm{~b}$ dysregulation in myeloid leukemogenesis and the therapeutic promise of regulating miR-29a/29b expression for myeloid leukemia in the future.

\section{Abbreviations}

AML: Acute myeloid leukemia; CML: Chronic myeloid leukemia; HI: Healthy individual Mcl-1, Myeloid cell leukemia sequence 1; BCl-2: B-cell lymphoma 2; RT-PCR: Reverse transcription-polymerase chain reaction; PBMCs: Peripheral blood mononuclear cells; $\beta 2$-MG: $\beta 2$-microglobulin; LSCs: Leukemia stem cells; CMP: Common myeloid progenitors; CLL: Chronic lymphocytic leukemia; MCL: Mantle cell lymphoma; HCC: Hepatocellular carcinomas.

\section{Competing interests}

The authors declare that they have no competing interests.

\section{Authors' contribution}

YQL directed and conceived the study and discussion. $L X$ and YQL were involved in manuscript preparation. YX, ZYJ XW, XFZ, CWZ, SHC, LYY, GXL, BL performed a part of experiments. All authors reviewed and assisted in revising the manuscript. All authors read and approved the final manuscript.

\section{Acknowledgements}

The study was supported by grants from the National Natural Science Foundation of China (nos. 81100353, 91129720,81270604,U1301226), the Natural Science Foundation of GuangdongProvince, China (no. S2013020012863), the Guangdong Science \& Technology Project (2012B050600023) and the Fundamental Research Funds for the Central Universities (Nos. 21610603, 21612116).

\section{Author details}

'Institute of Hematology, Medical College, Jinan University, Guangzhou 510632, China. ${ }^{2}$ Key Laboratory for Regenerative Medicine of Ministry of Education, Jinan University, Guangzhou 510632, China. ${ }^{3}$ Department of clinical laboratory, First Affiliated Hospital, Jinan University, Guangzhou 510632, China.

Received: 11 March 2014 Accepted: 31 May 2014

Published: 1 July 2014

\section{References}

1. Lowenberg B, Downing JR, Burnett A: Acute myeloid leukemia. N Engl J Med 1999, 341:1051-1062.

2. Estey E, Dohner H: Acute myeloid leukaemia. Lancet 2006, 368:1894-1907.

3. Hehlmann R, Hochhaus A, Baccarani M, European L: Chronic myeloid leukaemia. Lancet 2007, 370:342-350.

4. Garzon R, Heaphy CE, Havelange V, Fabbri M, Volinia S, Tsao T, Zanesi N, Kornblau SM, Marcucci G, Calin GA, Andreeff M, Croce CM: MicroRNA 29b functions in acute myeloid leukemia. Blood 2009, 114:5331-5341.

5. Sun YM, Lin KY, Chen YQ: Diverse functions of miR-125 family in different cell contexts. J Hematol Oncol 2013, 6:6.

6. Jin $Y$, Peng D, Shen $Y, X u$ M, Liang $Y$, Xiao B, Lu J: MicroRNA-376c inhibits cell proliferation and invasion in osteosarcoma by targeting to transforming growth factor-alpha. DNA Cell Biol 2013, 32:302-309. 
7. Fernando TR, Rodriguez-Malave NI, Rao DS: MicroRNAs in B cell development and malignancy. J Hematol Oncol 2012, 5:7

8. Zhao H, Wang D, Du W, Gu D, Yang R: MicroRNA and leukemia: tiny molecule, great function. Crit Rev Oncol Hematol 2010, 74:149-155.

9. Liao R, Xu Y, Chen M, Chen X, Zhan X, Sun J: Molecular mechanism of microRNA involvement in genesis of myelodysplastic syndrome and its transformation to acute myeloid leukemia. Hematology 2013, 18:191-197.

10. Jongen-Lavrencic M, Sun SM, Dijkstra MK, Valk PJ, Lowenberg B: MicroRNA expression profiling in relation to the genetic heterogeneity of acute myeloid leukemia. Blood 2008, 111:5078-5085.

11. Marcucci G, Mrózek K, Radmacher MD, Garzon R, Bloomfield CD: The prognostic and functional role of microRNAs in acute myeloid. Blood 2011, 117:1121-1129.

12. Zhang HCZ, Wang $X$, Huang $Z$, He Z, Chen $Y$ : Long non-coding RNA: a new player in cancer. J Hemato Oncol 2013, 6:37.

13. Joshi D, Gosh K, Vundinti BR: MicroRNAs in hematological malignancies: a novel approach to targeted therapy. Hematology 2012, 17:170-175

14. Labbaye C, Testa U: The emerging role of MIR-146A in the control of hematopoiesis, immune function and cancer. J Hematol Oncol 2012, 5:13.

15. Santanam U, Zanesi N, Efanov A, Costinean S, Palamarchuk A, Hagan J, Volinia S, Alder H, Rassenti L, Kipps T, Croce CM, Pekarsky Y: Chronic lymphocytic leukemia modeled in mouse by targeted miR-29 expression. Proc Natl Acad Sci USA 2010, 107:12210-12215.

16. Zhao JJ, Lin J, Lwin T, Yang H, Guo J, Kong W, Dessureault S, Moscinski LC, Rezania D, Dalton WS, Sotomayor E, Tao J, Cheng JQ: microRNA expression profile and identification of miR-29 as a prognostic marker and pathogenetic factor by targeting CDK6 in mantle cell lymphoma. Blood 2010, 115:2630-2639

17. Yanaihara N, Caplen N, Bowman E, Seike M, Kumamoto K, Yi M, Stephens RM, Okamoto A, Yokota J, Tanaka T, Calin GA, Liu CG, Croce CM, Harris CC: Unique microRNA molecular profiles in lung cancer diagnosis and prognosis. Cancer Cell 2006, 9:189-198.

18. Xiong Y, Fang JH, Yun JP, Yang J, Zhang Y, Jia WH, Zhuang SM: Effects of microRNA-29 on apoptosis, tumorigenicity, and prognosis of hepatocellular carcinoma. Hepatology 2010, 51:836-845.

19. Gebeshuber CA, Zatloukal K, Martinez J: miR-29a suppresses tristetraprolin, which is a regulator of epithelial polarity and metastasis. EMBO Rep 2009, 10:400-405.

20. Philippidou D, Schmitt M, Moser D, Margue C, Nazarov PV, Muller A, Vallar L, Nashan D, Behrmann I, Kreis S: Signatures of microRNAs and selected microRNA target genes in human melanoma. Cancer Res 2010, 70:4163-4173.

21. Schmitt MJ, Margue C, Behrmann I, Kreis S: MiRNA-29: A microRNA Family with Tumor-Suppressing and Immune-Modulating Properties. Curr Mol Med 2013, 13:572-585

22. Doran J, Strauss WM: Bio-informatic trends for the determination of miRNA-target interactions in mammals. DNA Cell Biol 2007, 26:353-360.

23. Llambi F, Green DR: Apoptosis and oncogenesis: give and take in the BCL-2 family. Curr Opin Genet Dev 2011, 21:12-20.

24. Mott JL, Kobayashi S, Bronk SF, Gores GJ: mir-29 regulates $\mathrm{Mcl}-1$ protein expression and apoptosis. Oncogene 2007, 26:6133-6140.

25. Gimenes-Teixeira HL, Lucena-Araujo AR, Dos Santos GA, Zanette DL, Scheucher PS, Oliveira LC, Dalmazzo LF, Silva-Júnior WA, Falcão RP, Rego EM: Increased expression of miR-221 is associated with shorter overall survival in T-cell acute lymphoid leukemia. Exp Hematol Oncol 2013, 2:10.

26. Li Y, Chen S, Yang L, Chen S, Lin C, Wang L, Lu Y, Geng S, Du X, Schmidt CA: Change in expression pattern of TCR-CD3 complex in patients with multiple myeloma. Hematology 2011, 16:143-150.

27. Dweep H, Sticht C, Pandey P: Gretz N: miRWalk-database: prediction of possible miRNA binding sites by "walking" the genes of three genomes. J Biomed Inform 2011, 44:839-847.

28. Garzon R, Liu S, Fabbri M, Liu Z, Heaphy CE, Callegari E, Schwind S, Pang J, Yu J, Muthusamy N, Havelange V, Volinia S, Blum W, Rush LJ, Perrotti D, Andreeff M, Bloomfield CD, Byrd JC, Chan K, Wu LC, Croce CM, Marcucci G: MicroRNA-29b induces global DNA hypomethylation and tumor suppressor gene reexpression in acute myeloid leukemia by targeting directly DNMT3A and 3B and indirectly DNMT1. Blood 2009, 113:6411-6418.

29. Steiner DF, Thomas MF, Hu JK, Yang Z, Babiarz JE, Allen CD, Matloubian M, Blelloch $\mathrm{R}$, Ansel KM: MicroRNA-29 regulates T-box transcription factors and interferon-gamma production in helper T cells. Immunity 2011, 35:169-181.
30. Wang $F$, Wang $X S$, Yang GH, Zhai PF, Xiao Z, Xia LY, Chen LR, Wang $Y$, Wang XZ, Bi LX, Liu N, Yu Y, Gao D, Huang BT, Wang J, Zhou DB, Gong JN, Zhao HL, Bi XH, Yu J, Zhang JW: miR-29a and miR-142-3p downregulation and diagnostic implication in human acute myeloid leukemia. Mol Biol Rep 2012, 39:2713-2722.

31. Garzon R, Volinia S, Liu C, Fernandez-Cymering C, Palumbo T, Pichiorri F, Fabbri M, Coombes K, Alder H, Nakamura T, Flomenberg N, Marcucci G, Calin GA, Kornblau SM, Kantarjian H, Bloomfield CD, Andreeff M, Croce CM: MicroRNA signatures associated with cytogenetics and prognosis in acute myeloid leukemia. Blood 2008, 111:3183-3189.

32. Garzon R, Garofalo M, Martelli MP, Briesewitz R, Wang L, Fernandez-Cymering C, Volinia S, Liu CG, Schnittger S, Haferlach T, Liso A, Diverio D, Mancini M, Meloni G, Foa R, Martelli MF, Mecucci C, Croce CM, Falini B: Distinctive microRNA signature of acute myeloid leukemia bearing cytoplasmic mutated nucleophosmin. Proc Natl Acad Sci USA 2008, 105:3945-3950.

33. Han YC, Park CY, Bhagat G, Zhang J, Wang Y, Fan JB, Liu M, Zou Y, Weissman IL, Gu H: microRNA-29a induces aberrant self-renewal capacity in hematopoietic progenitors, biased myeloid development, and acute myeloid leukemia. J Exp Med 2010, 207:475-489.

34. San Jose-Eneriz E, Roman-Gomez J, Jimenez-Velasco A, Garate L, Martin V, Cordeu L, Vilas-Zornoza A, Rodriguez-Otero P, Calasanz MJ, Prosper F, Agirre $X$ : MicroRNA expression profiling in Imatinib-resistant Chronic Myeloid Leukemia patients without clinically significant ABL1-mutations. Mol Cancer 2009, 8:69.

35. Machova Polakova K, Lopotova T, Klamova H, Burda P, Trneny M, Stopka T, Moravcova J: Expression patterns of microRNAs associated with CML phases and their disease related targets. Mol Cancer 2011, 10:41.

36. Li Y, Wang H, Tao K, Xiao Q, Huang Z, Zhong L, Cao W, Wen J, Feng W: miR-29b suppresses CML cell proliferation and induces apoptosis via regulation of BCR/ABL1 protein. Exp Cell Res 2013, 319:1094-1101.

37. Lee TY, Ezelle HJ, Venkataraman T, Lapidus RG, Scheibner KA, Hassel BA: Regulation of human RNase-L by the miR-29 family reveals a novel oncogenic role in chronic myelogenous leukemia. J Interferon Cytokine Res 2013, 33:34-42

38. Kaufmann SH, Karp JE, Svingen PA, Krajewski S, Burke PJ, Gore SD, Reed JC Elevated Expression of the Apoptotic Regulator Mcl-1 at the Time of Leukemic Relapse. Blood 1998, 91:991-1000.

39. Ye Y, Hu Z, Lin Y, Zhang C, Perez-Polo JR: Downregulation of microRNA-29 by antisense inhibitors and a PPAR-gamma agonist protects against myocardial ischaemia-reperfusion injury. Cardiovasc Res 2010, 87:535-544.

40. Campos L, Rouault JP, Sabido O, Oriol P, Oubi N, Vasselon C, Archimbaud E, Magaud JP, Guyotat D: High Expression of bcl-2 Protein in acute myeloid leukemia cells is associated with poor response to chemotherapy. Blood 1993, 81:3091-3096.

41. Tóthová EFM, Stecová N, Kafková A, Elbertová A: High expression of Bcl-2 protein in acute myeloid leukemia cells is associated with poor response to chemotherapy. Neoplasma 2002, 49:141-144.

42. Tsujimoto $Y$, Cossman J, Jaffe $E_{\text {, Croce }}$ CM: Involvement of the bcl-2 gene in human follicular lymphoma. Science 1985, 228:1440-1443.

43. Monni O, Joensuu H, Franssila K, Klefstrom J, Alitalo K, Knuutila S: BCL2 overexpression associated with chromosomal amplification in diffuse large B-cell lymphoma. Blood 1997, 90:1168-1174

44. Hanada M, Delia D, Aiello A, Stadtmauer E, Reed JC: bcl-2 gene hypomethylation and high-level expression in B-cell chronic lymphocytic leukemia. Blood 1993 82:1820-1828.

45. Calin GA, Ferracin M, Cimmino A, Di Leva G, Shimizu M, Wojcik SE, lorio MV, Visone R, Sever NI, Fabbri M, Iuliano R, Palumbo T, Pichiorri F, Roldo C, Garzon R, Sevignani C, Rassenti L, Alder H, Volinia S, Liu CG, Kipps TJ, Negrini M, Croce CM: A MicroRNA signature associated with prognosis and progression in chronic lymphocytic leukemia. N Engl J Med 2005, 353:1793-1801.

46. Xia L, Zhang D, Du R, Pan Y, Zhao L, Sun S, Hong L, Liu J, Fan D: miR-15b and miR-16 modulate multidrug resistance by targeting BCL2 in human gastric cancer cells. Int J Cancer 2008, 123:372-379.

doi:10.1186/2162-3619-3-17

Cite this article as: Xu et al: Altered expression pattern of miR-29a, $\mathrm{miR}-29 \mathrm{~b}$ and the target genes in myeloid leukemia. Experimental Hematology \& Oncology 2014 3:17 